\title{
Praktikalitas Perancangan dan Pengembangan Mobile Learning Berbasis Android Sebagai Media Pembelajaran Mandiri di Perguruan Tinggi
}

\author{
Aminda Dewi Sutiasih ${ }^{1}$, Renny Permata Saputri ${ }^{2}$ \\ Universitas Putra Indonesia "YPTK" Padang, Padang \\ amindadewi@upiyptk.ac.id ${ }^{1}$,renny_permata@upiyptk.ac.id ${ }^{2}$
}

\begin{abstract}
This research is in the background behind the habits of students in using smartphones, most of which are only used to access social networks and have not taken an important role in the field of education. The purpose of this study is to design mobile learning for computer architecture organizational subjects. The research method used in this study is Research and Development ( $R \& D)$ using the Instructional Development Institute (IDI) development model which includes three stages,namely(1)define:needs analysis, (2)develop:product development, and (3) evaluate:product trial. Based on the results of practical tests conducted with students and lecturers, it was found that this learning media can be categorized as practical to be used as an Android-based mobile learning. The results of this study indicate that mobile learning for computer architecture organizational subjects is practical to be used as a supporting media for independent learning, in accordance with the results of the lecturers' practical test of $91 \%$ and student practice results of $87.62 \%$ and includes very practical categories. From the results of the practical test, it can be concluded that the Android-based Mobile Learning media as a practical learning media is used for computer architecture organizational subjects in university.
\end{abstract}

Keywords : Mobile learning, Research and Development, Practicality

Abstrak- Penelitian ini di latar belakangi oleh kebiasaan di kalangan mahasiswa dalam menggunaan smartphone, sebagian besar hanya digunakan untuk mengakses jejaring sosial dan belum mengambil peranan penting di bidang pendidikan. Tujuan Penelitian ini untuk merancang media pembelajaran mobile learning pada matakuliah organisasi arsitektur komputer berbasis android. Metode penelitian yang digunakan dalam penelitian ini adalah Research and Development (R\&D) dengan menggunakan model pengembangan Instructional Development Institute (IDI) yang meliputi tiga tahap yaitu (1) define: analisis kebutuhan,(2)develop:pengembangan produk,dan(3)evaluate:ujicoba produk. Berdasarkan pada hasil uji praktikalitas yang dilakukan dengan mahasiswa dan dosen didapatkan hasil bahwa media pembelajaran ini dapat dikategorikan praktis untuk digunakan sebagai media pembelajaran mobile learning berbasis android. Hasil penelitian ini menunjukkan bahwa mobile learning untuk matakuliah organisasi arsitektur komputer ini praktis untuk dimanfaatkan sebagai media pendukung pembelajaran mandiri, sesuai dengan hasil uji praktikalitas dosen yaitu 91\% serta hasil uji praktikalitas mahasiswa yaitu $87.62 \%$ yang termasuk kategori sangat praktis. Dari hasil uji praktikalitas tersebut maka dapat disimpulkan bahwa media pembelajaran Mobile Learning berbasisi Android sebagai media pembelajaran praktis digunakan untuk matakuliah organisasi arsitektur komputer di Perguruan Tinggi.

Kata Kunci: Mobile Learning, Research and Development, Praktikalitas 


\section{PENDAHULUAN}

Seiring dengan berkembangnya arus globalisasi, dunia mengalami perubahan teknologi menuju pada kemajuan zaman dimana diciptakannya teknologi yang memudahkan kegiatan manusia. Salah satunya adalah dengan berkembangnya smartphone. Di Indonesia sendiri dikutip dari kemenperingo.id mengatakan bahwa pertumbuhan ponsel di Indonesia mencapai 62\% per tahun. Namun seiring dengan kemajuan teknologi dan banyaknya pengguna smartphone di Indonesia berbanding terbalik dengan pemanfaatan smartphone yang belum optimal khususnya di dunia pendidikan. Berdasarkan pengamatan yang dilakukan dapat diasumsikan bahwa mayoritas mahasiswa memanfaatkan smartphone hanya sebatas untuk telepon, SMS, memutar lagu atau video, mengakses sosial network facebook, twitter, BBM, bahkan bermain game. Mobile learning mampu menja,dikan smartphone yang awalnya hanya digunakan untuk sms, telepon atau internet menjadi alat belajar lengkap yang berisi materi pembelajaran yang terdiri dari materi, soal, dan kuis dan dilengkapi berbagai fitur. Penggunaan smartphone sangat membantu semua orang mulai dari mempermudah pekerjaan, media pembelajaran dan alat komunikasi. Hal ini merubah pola hidup semua orang yang memanfaatkan smartphone untuk meningkatkan kemudahan dalam kehidupan mereka sehari-hari, tidak terkecuali dalam proses pembelajaran, setiap individu mulai beradaptasi dengan situasi pembelajaran yang baru dengan inovasi-inovasi yang ada pada saat ini seperti Mobile Learning.

Pembelajaran Mobile Learning memiliki dampak yang sangat baik bagi pembelajaran karena melalui Mobile Learning mahasiswa juga dapat berhubungan dengan dosen pengampu serta peserta didik lainnya dengan mengandalkan koneksi dari internet. Teknologi yang ditawarkan oleh Mobile Learning tidak membatasi pembelajaran yang hanya pada jadwal tatap muka, oleh karena itu kordinasi penggunaan Mobile Learning dalam pembelajaran menawarkan kemajuan yang luar biasa di masa depan, dapat disimpulkan bahwa penggabungan teknologi Mobile Learning dalam pembelajaran dapat meningkatkan efektifitas dan aksebilitas kegiatan pemebelajaran dimasa depan. Di masa depan pengembangan aplikasi Mobile Learning akan sangat berkembang dan membantu peserta didik dalam penyelesaiaan tugas dan materi pembelajaran melalui smartphone yang mereka punya. Batasan masalah dalam penelitian ini adalah untuk mengetahui Mobile Learning berbasis Android dapat membantu mahasiswa untuk belajar secara mandiri. Media pendukung yang dihasilkan tidak hanya monoton dengan teks saja, tetapi juga memuat unsur-unsur multimedia audio/visual bahkan animasi yang memudahkan mahasiswa dalam memahami materi perkuliahan.

\section{METODOLOGI PENELITIAN}

\subsection{Media Pembelajaran}

Media pembelajaran adalah bahan, alat, maupun metode atau teknik yang digunakan dalam kegiatan belajar mengajar dengan maksud agar proses interaksi dan komunikasi antara pendidik dan peserta didik menjadi efektif dan dapat dimengerti. klasifikasi media yang dapat digunakan dalam kegiatan pembelajaran, yaitu 1) Media yang tidak diproyeksikan, 2) Media yang diproyeksikan, 3) Media audio, 4) Multimedia, 5) Film dan video. Sesuatu dapat dikatakan sebagai media 
pembelajaran apabila digunakan untuk menyalurkan atau menyampaikan pesan dengan tujuan-tujuan pendidikan dan pembelajaran.

\subsection{Mobile Learning}

Mobile learning sangat berpotensi untuk merubah efisiensi dalam dunia pendidikan walaupun dengan area yang sangat luas. Dengan berkembangnya platform mobile yang sangat pesat, kita diharuskan untuk menghadapi segala sesuatunya dengan aplikasi mobile. Perangkat pendukung mobile learning merupakan prasyarat dasar bagi berlangsungnya proses pembelajaran dengan menggunakan mobile learning. Mobile Learning merupakan model pembelajaran yang dilakukan antar tempat atau lingkungan dengan menggunakan teknologi yang mudah dibawa pada saat pembelajar berada pada kondisi mobile/ponsel. Dengan berbagai potensi dan kelebihan yang dimilikinya, Mobile Learning diharapkan akan dapat menjadi sumber belajar alternatif yang dapat meningkatkan efisiensi dan efektifitas proses dan hasil belajar peserta didik di Indonesia dimasa datang.

\subsection{Metodologi Penelitian}

Perancangan mobile learning berbasis android pada mata kuliah organisasi arsitektur komputer untuk mahasiswa semester genap program studi Pendidikan Teknik Informatika Merupakan penelitian dan pengembangan (research and development). Produk yang dihasilkan tersebut tidak selalu berbentuk benda seperti buku, alat tulis, dan alat pembelajaran lainnya. Namun dapat pula dalam bentuk perangkat lunak (software). Untuk dapat menghasilkan produk tertentu digunakan penelitian yang bersifat analisis kebutuhan dan untuk menguji keefektifan produk tersebut supaya dapat berfungsi di masyarakat luas, maka diperlukan penelitian untuk menguji keefektifan produk tersebut. Sepuluh langkah pada metode penelitian dan pengembangan yang di tunjukan dalam bagan pada gambar 1.

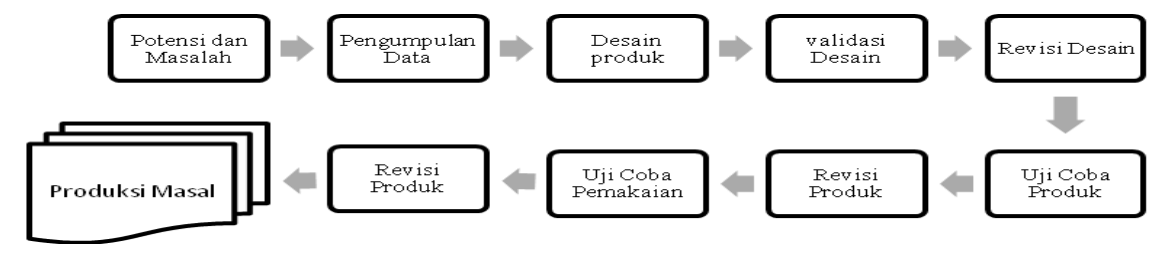

Gambar 1.Langkah-langkah penggunaan Metode Research and Development (R\&D)

\subsection{Prosedur Pengembangan}

Media pembelajaran Mobile Learning berbasis Android dikembangkan dengan menggunakan model IDI, yang terdiri dari tahap penentuan (define), pengembangan (develop), dan evaluasi (evaluate) Secara garis besar pengembangan ini dapat dilihat dari gambar dibawah ini : 


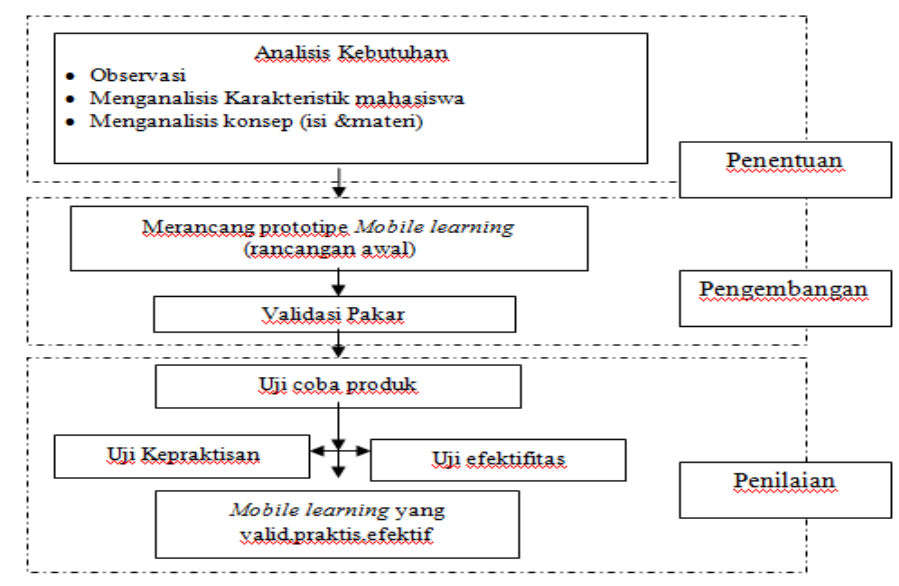

Gambar 2. Desain Pengembangan Mobile Learning

Tahap Penentuan (Define) mencakup Pelaksanaan penelitian diawali dengan tahap penentuan (define) dengan tujuan menetapkan dan mendefinisikan syaratsyarat pembelajaran terdiri dari analisa konsep dan analisis karakteristik mahasiswa. Tahap Pengembangan mencakup perancangan prototype, tahap validasi. Tahap evaluasi kegiatan dipusatkan untuk mengevaluasi apakah rancangan awal (prototipe) dapat digunakan sesuai dengan harapan dan efektif sebagai media pendukung pemebelajaran mahasiswa meliputi uji coba produk, tahap praktikalitas, tahap efektifitas.

\subsection{Pengambilan dan Pengujian Data}

Pengambilan data uji praktikalitas dilakukan dengan menggunakan instrument Angket yang merupakan assessment yang dinilai oleh mahasiswa dan dosen pada matakuliah organisasi arsitektur komputer program studi Pendidikan Teknik Informatika.

\section{HASIL DAN PEMBAHASAN}

\subsection{Hasil Perancangan Mobile learning Berbasis Android}

Berikut merupakan tampilan halaman home pada mobile learning organisasi arsitektur komputer dapat di lihat pada gambar 3.

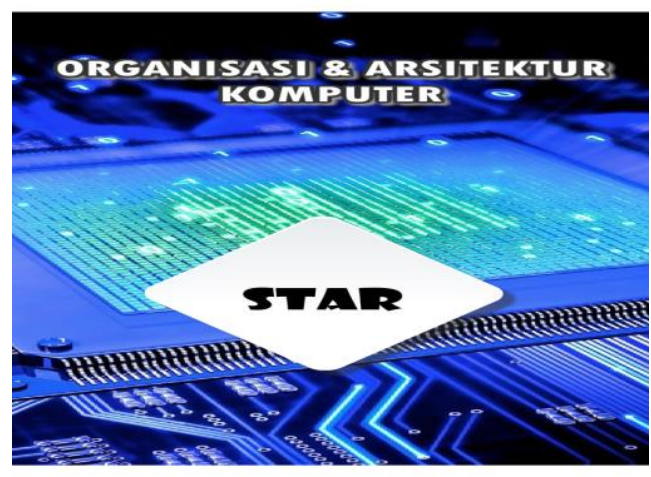

Gambar 3. Tampilan Halaman Home 
Home merupakan halaman depan atau halaman utama tampilan awal mobile learning berbasis android yang berisi pengantar ucapan selamat datang pada aplikasi mobile learning organisasi arsitektur komputer. Berikut Tampilan halaman akses Menu, dapat dilihat pada gambar 4.

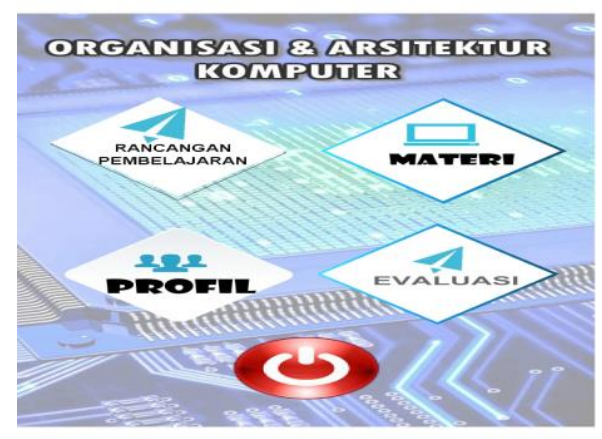

Gambar 4. Tampilan Halaman Menu

Tampilan halaman menu ini merupakan halaman akses untuk pengguna mahasiswa ataupun dosen serta akses informasi tentang mobile learning yang berisikan rancangan pembelajaran, materi, profil dan evaluasi. Berikut Tampilan halaman akses Materi, dapat dilihat pada gambar 5.

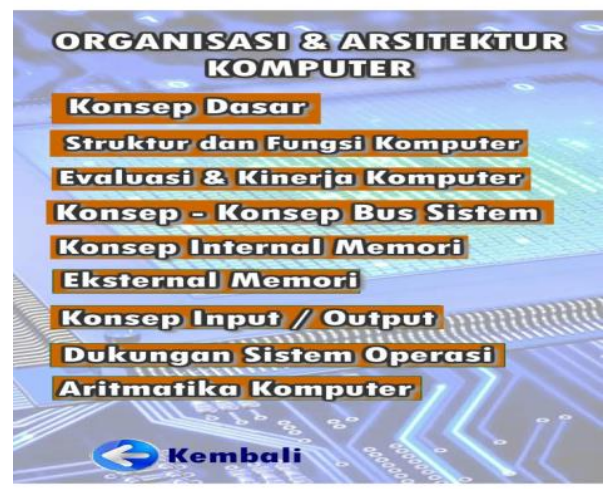

Gambar 5. Tampilan Halaman Materi

Tampilan Akses halaman materi terdiri dari materi pada mata kuliah organisasi arsitektur komputer sesuai dengan rancangan pembelajaran. Kemudian berikut merupakan Akses halaman evaluasi, dapat dilihat pada gambar 6 .

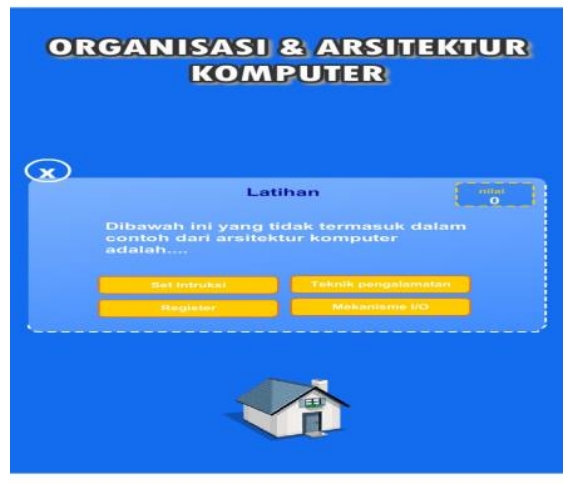




\section{Gambar 6. Tampilan Halaman Evaluasi}

Halaman ini berisikan evaluasi pembelajaran yang dilakukan oleh mahasiswa, pada tampilan ini disajikan soal-soal yang berhubungan dengan mata kuliah organisasi arsitektur komputer.

\subsection{Pembahasan dan Hasil Uji Praktikalitas}

Praktikalitas berkaitan dengan kemudahan dalam penggunaaan mobile learning yang dikembangkan. Data praktikalitas diperoleh melalui angket yang diisi oleh dua orang praktisi dosen didapatkan rata-rata hasil uji praktikalitas adalah 91\%. Penilaian hasil uji praktikalitas ini berdasarkan pada kriteria: (1) Teknis (2) Isi (3) desain dengan total jumlah butir pertanyaan sebanyak 20 buah. Hasil uji praktikalitas tersebut dapat dilihat pada hasil pengolahan data yang berbentuk diagram distribusi frekuensi. Dapat dilihat pada gambar 7.

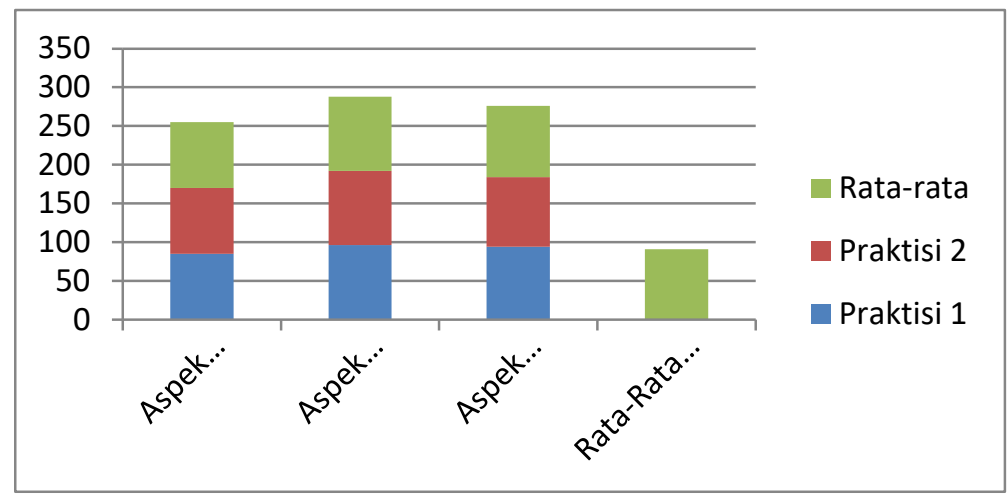

Gambar 7. Diagram Hasil Uji Praktikalitas Dosen

Praktikalitas mobile learning juga memerlukan masukan berupa respon dari mahasiswa. Data ini didapatkan setelah dilakukan pembelajaran, melalui angket yang diberikan kepada mahasiswa didapatkan rata-rata hasil uji praktikalitas adalah $87.62 \%$. Penilaian hasil uji praktikalitas ini berdasarkan pada kriteria: (1) Kemudahan (2) Motivasi (3) Kemenarikan (4) kemanfaatan dengan total jumlah butir pertanyaan sebanyak 24 buah. Hasil uji praktikalitas tersebut dapat dilihat pada hasil pengolahan data yang berbentuk diagram distribusi frekuensi. Dapat dilihat pada gambar 8 .

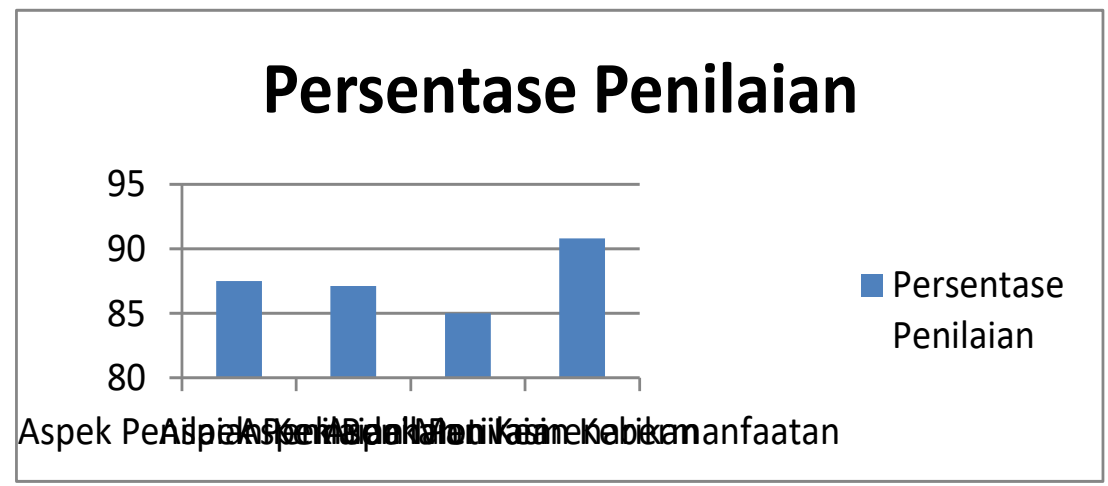

Gambar 8. Diagram Hasil Uji Praktikalitas Mahasiswa. 


\section{KESIMPULAN}

Mekanisme pengembangan mobile learning organisasi arsitektur komputer berbasis Android sebagai media pendukung pembelajaran mandiri melalui analisis kebutuhan yang dibutuhkan oleh mahasiswa dan dosen. Pengujian praktikalitas pada penelitian ini di isi oleh 2 orang dosen dengan hasil hasil uji praktikalitas 91\% berada pada kriteria Sangat praktis. Selanjutnya pengujian praktikalitas dilakukan kepada mahasiswa dengan hasil uji praktikalitas 87,62\% dengan kategori sangat praktis. Uji Praktikalitas mobile learning organisasi arsitektur komputer berbasis Android sebagai media pembelajaran mandiri menyatakan bahwa mobile learning praktis. Setelah dilakukan pengujian Praktikalitas nantinya akan dikembangkan ke pada pengujian selanjutnya, yaitu keefektifan langsung pada objek penelitian perguruan tinggi khususnya Kota Padang.

\section{DAFTAR PUSTAKA}

[1] Arsyad, Azhar. 2011. Media Pembelajaran. Jakarta : Raja Grafindo Persada

[2] Djamarah, Syaiful B dan Zain, Aswan. 2010. Strategi Belajar Mengajar. Jakarta: Rineka Cipta.

[3] Keegan, D. 2005. The incorporation of mobile learning into mainstream education and training. In World Conference on Mobile Learning, Cape Town, (online). Diakses 10 Januari 2018

[4] Solichin, Achmad dan Gatot Wicaksono. 2013. Aplikasi Mobile Learning Pada D3 Unggulan Universitas Budi Luhur. SESINDO 2013

[5] Sugiyono.2013. Metode Penenlitian Kuantitatif, Kualitatif, dan R\&D: Bandung. Alfabeta 